\title{
Effects of Religiosity, Peer Attachment, Characteristics of Instagram social media usage on Hedonic Behavior
}

\author{
Tina Deviana ${ }^{1}$, Nia Tresniasari ${ }^{2}$, Rena Latifa $^{3}$ \\ tinadeviana22@gmail.com ${ }^{1}$,tresniasari.nia@gmail.com ${ }^{2}$,rena.latifa@uinjkt.ac.id ${ }^{3}$ \\ ${ }^{123}$ Faculty of Psychology, State Islamic University Syarif Hidayatullah Jakarta
}

\begin{abstract}
This study aimed to examine the prediction of religiosity, peer attachment, instagram on hedonic behavior. Hedonic behavior is a pattern of life that directs its activities to seek the pleasure of life, so that the forms of behavior that are raised in hedonic behavior usually spend more time outside the home to have fun with friends, love to give things that are not needed, and always want to be attention to the surrounding environment (Well and Tigert in Engel, [18]). The design used in this study was multiple regression research design. The result showed that: (1) religiosity, peer attachment, instagram contributed effect about $18.2 \%\left(\mathrm{R}_{2}\right.$ $=0.182$ ) on hedonic behavior. (2) Based on the results of hypothesis testing of each variable that has been carried out there are three independent variables that have a significant effect on hedonic behavior, namely sinful acts by religiosity, instagram usage, and number of followers.
\end{abstract}

Keywords: hedonic behavior; religiosity; peer attachment; instagram

\section{Introduction}

The study of Muslim hijab women living in urban areas is at the center of attention. Changes that occur can be seen in aspects of social life in society. The aspect of social life that occurs in modern Muslim women is expressed through clothing and hijab. Fashion and hijab expression indirectly forms a hedonic lifestyle [1][2] which will be the topic of this research. In the last 5 years research on hedonic lifestyles was found among adolescents ([3]; [4], [5]; [6] [7]; [8]; [9]).

The phenomenon of hedonic lifestyle has been discussed in various universities in Indonesia. This is evidenced by research using case studies [10] ; [11]; [12] that hedonic behavior is found in students. The case study shows that the hedonic lifestyle considers the pleasures and pleasures of life as the main goals in one's life. [13] conducted a survey on 19-20 November 2014 to 50 students from various faculties in Malang City University. The survey results are known to see the activities most often carried out by students, namely traveling to the mall $(24 \%)$ and spending time at the café $(24 \%)$, watching the cinema $(17 \%)$, going to the bookstore $(10 \%)$, hangout with friends $(9 \%)$, learning to understand the material from lecturers $(7 \%)$, playing games $(5 \%)$, and going to the library (3\%). The results of the survey were the activities most often carried out by students were to go to the mall and spend time at the café. Hamzah's research [14] in Malaysia which discusses hedonic lifestyles in students refers to "hedonistic behavior" or hedonic behavior that is demonstrated such as squandering money, and spending time outside the home to achieve enjoyment in life.

The hedonic lifestyle found in students is the headline that students are the next generation of the nation's progress, especially in the world of education. However, at present students tend to glorify the fun and enjoyment of living [15]. The phenomenon of Muslim hijab women who carry out hedonic behavior is supported by articles that discuss "Hedonism among Hijabers". Hedonic behavior is mostly aimed at the environment outside the home, tends to choose friends, wants to be the center of attention and orientation is only for pleasure in life [16]. The amount of data on hijab Muslim women who have hedonic behavior is not shown in this article. The hedonic behavior that is meant by Muslim women in hijab is a group of people in a community. A group of people have shown hedonic behavior to see themselves only for social status. This is indicated by the dresscode provisions, even though the agenda of the event they participated in was a social service just to show pleasure. Hedonic behavior in Muslim hijab women is contrary to the meaning of hijab which is a form of obedience and obedience of a Muslim woman in carrying out the commands of religious Shari'a. If the hedonist lifestyle really begins to enter the behavior of Muslim women wearing hijab, this is due to the low spirit and theological awareness among them. Muslim women wear hijab is not based on spiritual awareness alone, but is more influenced by fashion trends alone [17] 
Hedonic behavior is meant a pattern of life that directs activities to seek the pleasure of life. The forms of behavior shown usually spend more time outside the home to have fun with friends, love to give things that are not needed, and always want to be attentive to the surrounding environment. [18]

Previous studies on hedonic behavior were influenced by several internal and external factors. Internal factors that influence hedonic behavior are religiosity. Hedonic behavior is influenced by religiosity significantly in a negative direction [19][20]. External factors that influence hedonic behavior are peer attachments and the characteristics of the use of social media instagram., peer attachment was found that close friendship with peers became the main source of closeness to feelings and attitudes [21] [22] Hazan \& Zeifman, 1994; Wilkinson, 2008; Wilkinson 2010). Factors using instagram social media usage on hedonic behavior indicate that there are interrelationships with one's life satisfaction which are shown through likes and comments. Hedonic behavior is associated with feeling cool, fun and being an attractive person will cause a feeling of comfort on social media instagram [23][24]. The Casalo study is in line with the rapid development of social media which is considered an escape from boredom, filling up leisure time and relaxing.[25]

Alhabash \& Ma which states that the eight most important aspects of instagram use are all self-centered such as spending time, getting and sharing information, convenience, entertainment,self-expression, social interaction, and self-documentation [26] . Al-Hunaiyyan \& Al-Hajri explain that one can follow family, friends or strangers who show activities of daily life on Instagram social media [27]. Hu et.al. analyze the selection of content and types of users on Instagram. Many individuals upload selfie content to show themselves on the instagram [28]. Jang J. Y et.al.'s research shows that the use of likes, comments and Hastag in teenagers shows self-expression in interacting on social media instagram.[29]

The phenomena and previous studies described above, it can be concluded that this research is important. This is because a lot of new findings that will be obtained in this study have been explained previously. Therefore, to realize this the writer needs to conduct a study entitled "The effect of religiosity, peer attachment, and the characteristics of the use of Instagram social media on female hedonic behavior" 


\section{LITERATURE REVIEW.}

\subsection{Hedonic Behavior}

Hedonic behavior in the field of psychology is discussed in the field of positive psychology. Seligman argues that the happiness of a person to get a good life can be addressed through three ways, namely: (a) a happy life that is achieved through self-satisfaction, (b) living a good life with morale and strength, (c) life achieved to improve various p. Illustration of a good life is actually life that enjoys happiness but at the limits of good morality (eudaimonia) while things that transcend boundaries will provide various problems due to excessive (hedonism) (Seligman in Buhr). [30]

Hamzah et al specifically in psychological research using the term "hedonistic behavior". There are two "hedonistic behavior" perspectives used by Hamzah[31][32], namely the ethical perspective and psychological perspective. Hedonic behavior in an ethical perspective is discussed in philosophy, born of hedonism. The search for excessive pleasure is a virtue and moral value of an individual person. Hedonism in a psychological perspective is discussed in psychology. The search for excessive pleasure is a form of behavior that is shown to pursue sensations in his life. Someone who has a hedonic behavior unconsciously has the notion of hedonism. Hedonic behavior is characterized by openness to pleasant experiences and tends to pamper oneself with various desires of oneself.

From these various definitions, the term hedonism has also been summarized in the psychology dictionary where hedonism is the view that excessive pleasure or pleasure is a life goal described by individual behavior. [33]

In this study, the intended hedonic behavior is a lifestyle that directs its activities to seek life's pleasures, so that the forms of behavior that appear in hedonic behavior usually spend more time outside the house to have fun with their friends, like to give goods that not needed, and always wants to be a concern for the surrounding environment (Well and Tigert in Engel, 1993).

\subsection{Religiosity}

According to Olufadi religiosity is the extent to which the level of individual commitment to Islam and its teachings show beliefs, attitudes, and practices. The teachings of the Islamic religion are in accordance with the teachings of the Qur'an and the positive behavior shown by the Prophet Muhammad.[34]

There are three dimensions of religiosity, namely sinful acts, recommended acts, and Engaging in bodily worship of God. Sinful acts are someone who commits large and small sins which are prohibited in Islam. Someone is expected to avoid sinning because it will describe a person's higher religiosity. The Recommended Acts are positively recommended behaviors ordered by God and exemplified by the Prophet Muhammad. Engaging in bodily worship of God is someone who is obliged to worship fully involving himself only for Allah SWT such as obeying the command of prayer.

\subsection{Peer Attachment}

According to Armsden \& Greenberg peer attachment is someone forming bonds with peers in emotionally supportive social relationships that include a process[35]. The process is communication, trust, and alienation. If communication and trust in friends are good, then someone will not feel alienated (alienation). [36][37], Weiss $1982,[38] ;[39]$

\subsection{Instagram}

Instagram is social media used throughout the world. This application someone can share photos and videos with other users, Instagram has been commonly researched in the field of psychology when traced to recent articles in the field of psychology such as research from [40] [41] so that on the basis of the popularity of social media, various psychological factors related to the use of Instagram social media have been tested such as loneliness[42] orientation for social comparison.[43] body images [44], social adjustment [45], and hedonism [46]. According to Paramboukis the characteristics of Instagram social media usage are tracking the use of services for taking and sharing photos and videos on smartphones or computers consisting of several dimensions studied in the social 
and behavioral fields, namely: usage Instagram, Instagram behavior, Instagram attitudes, emotional Instagram reaction [47]

\section{Hypothesis Major :}

There is a significant influence from religiosity (sinful acts, recommended acts, engaging in bodily worship of God), peer attachment, characteristics of Instagram social media usage (instagram usage, instagram behavior, instagram attitude, instagram emotional reactions), and demographic factors (number of followers and age) towards hedonic behavior.

\section{Hypothesis Minor:}

Ha1: There is a significant effect of sinful acts on religiosity on hedonic behavior

Ha2: There is a significant effect of recommended acts on religiosity on hedonic behavior

Ha3: There is a significant influence of engaging in bodily worship of God on religiosity towards hedonic behavior

Ha4: There is a significant effect of peer attachment on hedonic behavior

Ha5: There is a significant influence of Instagram usage on the characteristics of Instagram social media use on hedonic behavior

Ha6: There is a significant influence of Instagram behavior on the characteristics of the use of Instagram social media on hedonic behavior

Ha7: There is a significant influence of Instagram attitudes on the characteristics of the use of Instagram social media on hedonic behavior

Ha8: There is a significant influence of instagram emotional reactions on the characteristics of the use of Instagram social media on hedonic behavior

Ha9: There is a difference in the group number of followers is high and number of followers is low in demographic factors for hedonic behavior

Ha10: There is a significant influence of age on demographic factors on hedonic behavior

\section{METHODOLOGY}

\subsection{Participants}

The participants in this study amounted to 335 people, Muslim women wearing hijab at Syarif Hidayatullah State Islamic University, Jakarta aged 17-25 years. Active participants use the Instagram social download account.

\subsection{Instrument}

\subsubsection{Hedonic Behavior}

In collecting hedonic behavior data, researchers modified from a hedonic behavior instrument developed by Well and Tigert (1993) with a 4 likert scale (very inappropriate, inappropriate, appropriate, very appropriate) that shows the frequency of behavior. This measuring instrument consists of 14 unidimensional items.

From the results of the CFA analysis, aunidimensional model was obtained. The measurement scale of hedonic behavior with one factor model obtained chi-square $=194,547$, df $=77 \mathrm{P}$ value $=0.00000$, and the value of $\mathrm{RMSEA}=1.0962$, meaning that the model is not fit.

Next, the authors make modifications to the model, where measurement errors on some items are free to correlate with each other Chi-square $=59.233, \mathrm{df}=64, \mathrm{P}$-value $=0.6454$, RMSEA $=0.000$, meaning that the model is fit. 
The results obtained that all items have T-value $>1.96$ ( $\mathrm{sig}$ ) and are positively charged. All items in this variable meet the criteria for model fit and no items are dropped. so that it can be used for further analysis.

\subsubsection{Religiosity}

The researcher adapted a measuring instrument from Olufadi that measures religiosity and is unidimensional in every dimension [48]. There are three dimensions of religiosity, namely sinful acts, recommended acts, and Engaging in bodily worship of God. From the results of the CFA analysis that measures the sinful acts of religiosity, the one-factor model obtained by Chi-square $=45.556, \mathrm{df}=35, \mathrm{P}$-value $=0.1091$, and the $\mathrm{RMSEA}=$ 0.030 , meaning that the model is fit.

From the results of the CFA analysis that measures recommended acts from religiosity, one model obtained Chisquare factor $=149,813, \mathrm{df}=14, \mathrm{P}$-value $=0.00000$, and RMSEA value $=0.170$, meaning the model is not fit. Next, the researcher modifies the model, where measurement errors on some items are free to correlate with each other, Chi-square $=14.211, \mathrm{df}=11, \mathrm{P}$-value $=0.2215$, RMSEA $=0.030$, which means the model is fit. Then, from the results of the CFA analysis that measures engaging in bodily worship of God, the one-factor model obtained by Chi-square $=152101, \mathrm{df}=14, \mathrm{P}$-value $=0.00000$, and RMSEA $=0.172$, meaning the model is not fit.

The results obtained that all items have T-value $>1.96$ (sig) and are positively charged. All items in this variable meet the criteria for model fit and no items are dropped. So that it can be used for further analysis.

\subsubsection{Peer Attachment}

Peer Attachment from Armsden and Greenberg with a 4 likert scale (very inappropriate, inappropriate, appropriate, very appropriate) that shows the frequency of behavior. This measuring instrument consists of 10 unidimensional items. [49]

From the results of the CFA analysis carried out with the one-factor model obtained Chi-square $=239,983, \mathrm{df}=$ 35 , P-value $=0.00000$, and the RMSEA value $=0.132$, meaning the model is not fit. Next, the writer modifies the model, where measurement errors on some items are free to correlate with each other, Chi-square $=36,414$, $\mathrm{df}=27, \mathrm{P}$-value $=0.1065$, and RMSEA $=0.032$, meaning the model is fit.

\subsubsection{Instagram}

The researcher modified the instagram instrument from Paramboukis with its three dimensions, namely usage Instagram, instagram of behavior, Instagram attitudes, emotional reaction instagram [50]. construct validity test results from 13 items with multifactor models. From the results of the CFA analysis. From the results of the CFA analysis conducted with a multifactor model obtained Chi-square $=305,110, \mathrm{df}=98, \mathrm{P}$-value $=0.00000$, and the value of RMSEA $=0.079$, meaning the model is not fit. Next the author modifies the model, where measurement errors on some items are free correlated with each other Chi-square $=103,982$, df $=94$, P-value $=0.2260$, RMSEA $=0.018$, meaning that the model is fit.

The results obtained that all items have T-value $>1.96$ (sig) and are positively charged. All items in this variable meet the criteria for model fit and no items are dropped. So that it can be used for further analysis.

\subsection{Data analysis method}

Before analyzing the data on each variable, the authors conducted the validity of the measuring instrument using the confirmatory factor analysis (CFA) method with MPLUS 7.11 software. Furthermore, in this study a regression analysis with multiple regression analysis will be conducted in which there are more than one independent variable to determine the effect on the dependent variable.

In this study there are ten independent variables and one dependent variable that will be regressed with SPSS 20 software. Through this multiple regression the coefficient of determination will be obtained, namely R2. R2 shows the variation or change in dependent variable $(\mathrm{Y})$ due to independent variable $(\mathrm{X})$, then used to determine 
the magnitude of the influence of independent variable $(\mathrm{X})$ on the dependent variable $(\mathrm{Y})$, and the estimated variance proportion of hedonic behavior explained by all independent variables.

\section{RESULT}

\subsection{Descriptive Statistics of Research Variables}

Tabel 4.1

Descriptive statistics of research variables

\begin{tabular}{lccccc}
\hline & N & Min & Max & Mean & SD \\
\hline Perilaku hedonis & 335 & 48.12 & 52.00 & 50 & 0.63 \\
Sinful acts & 335 & 45.85 & 55.01 & 50 & 1.61 \\
Recommended acts & 335 & 45.90 & 54.79 & 50 & 2.17 \\
Engaging in bodily & 335 & 47.68 & 52.88 & 50 & 0.81 \\
worship of God & & & & & \\
Peer attachment & 335 & 49.48 & 50.34 & 50 & 0.13 \\
Instagram usage & 335 & 49.28 & 56.43 & 50 & 1.43 \\
Instagram & 335 & 50.60 & 52.13 & 50 & 0.31 \\
Behavior & & & & & \\
Instagram attitude & 335 & 47.44 & 52.31 & 50 & 1.02 \\
Instagram & 335 & 50.32 & 60.75 & 50 & 2.16 \\
Emotional & & & & & \\
Reactions & & & & & \\
Number of & 335 & 12 & 6214 & 71 & 596 \\
Followers & & & & 0 & \\
Usia & 335 & 17 & 24 & 19 & 1.31 \\
\hline
\end{tabular}

It can be seen that the number of research subjects was 335 people. The mean in this study was made constant ie 50 with the aim of eliminating negative scores on the data. The hedonic behavior variable has the lowest score of 48.12 and the highest score is 52.00. The variable Sinful Acts has the lowest score of 45.85 and the highest score is 55.01. The Recommended Acts variable has the lowest score of 45.90 and the highest score is 54.79. The Engaging variable in bodily worship of God has the lowest score of 47.68 and the highest score is 52.88 .

The Peer Attachment variable has the lowest score of 49.48 and the highest score is 50.34 . The Instagram usage variable has the lowest score of 49.28 and the highest score is 56.43. The Instagram behavior variable has the lowest score of 50.60 and the highest score is 52.13. The variable Instagram attitude has the lowest score of 47.44 and the highest score is 52.31. Instagram emotional reactions variable has the lowest score of 50.32 and the highest score is 60.75 . The age variable has the lowest score of 17 and the highest score is 24 . The Number of followers variable has the lowest score of 12 and the highest score is 6214 .

By seeing descriptive statistics, a variable of "number of followers" does not follow a normal distribution. However the author translate "number of followers" to a categorical variable (dummy variable). At the time of regression analysis, researchers used the variable number of followers as an independent variable in this study. Number of followers is a continuum variable, but the researcher analyzes the variable by making it a categorical variable. This means that the number of followers variable is categorized as a dummy variable. The division of number of followers from the 
minimum value of 12 to 576 is said to be a low number of followers and given code 0 . And values 577 to 6213 are said to be a high number of followers and given code 1 . With this the regression coefficient will not occur error in number of followers variable.

\subsection{Regression Analysis Test Results}

The researcher has conducted a regression analysis test to find out which variables are significant for hedonic behavior. In regression there are two things seen, first looking at R-square (R2) aims to see the percentage (\%) of the dependent variable variance, that is, the hedonic behavior explained by the independent variable as a whole. Second, looking at the overall significance of independent variables towards the dependent variable as explained earlier. The final step is to see the contribution of each independent variable (R2-change) and the significance of the dependent variable. Next below is a table that shows $\mathrm{R}^{2}$ :

Tabel 4.2

Model Summary Regression Analysis

\begin{tabular}{ccccc}
\hline Model & R & R Square & $\begin{array}{c}\text { Adjusted R } \\
\text { square }\end{array}$ & $\begin{array}{c}\text { Standard } \\
\text { Error }\end{array}$ \\
\hline 1 & $.426^{\mathrm{a}}$ & .182 & .156 & 0.58056 \\
\hline
\end{tabular}

\section{Keterangan:}

DV: Dependent Variable

$\mathrm{R} ;$ Regression

$\mathrm{R}^{2}$ : Coefficient of determination

Adjusted $\mathrm{R}^{2}$ : Adjustable R2 value

S.E Estimate : Standar error

In table 4.2 , it appears that the value of $\mathrm{R}$ Square in this study is 0.182 or $18.2 \%$. This means that the influence of variables of religiosity (sinful acts, recommended acts, engaging in bodily worship of God), peer attachments, characteristics of the use of social media instagram (usage instagram, behavioral instagram, emotional attitude instagram) and demographic factors (number of followers, age) against hedonic behavior of $18.2 \%$. The remaining $81.8 \%$ is influenced by variables outside of this study.

The following information about regression coefficient IV is presented in table 4.3:

Tabel 4.3

Regression coefficient (standardized) of three IVs in predicting hedonic behavior 


\begin{tabular}{lllll}
\hline $\begin{array}{l}\text { Perilaku } \\
\text { Hedonis }\end{array}$ & $\mathrm{B}$ & $\mathrm{SE}$ & $\mathrm{T}$-value & P-value \\
\hline Sinful acts & 0.147 & 0.0 & 6.9 & $0.000^{*}$ \\
& & 21 & 11 & \\
& & & & \\
$\begin{array}{l}\text { Instagram } \\
\text { Usage }\end{array}$ & -0.151 & 0.044 & -2. & $0.040^{*}$ \\
& & & 06 & \\
$\begin{array}{l}\text { Number of } \\
\text { followers }\end{array}$ & 0.136 & 0.066 & 2.0 & $0.040^{*}$ \\
\hline
\end{tabular}

Notes:

*) : Significants $(\mathrm{p}<0.05)$

Based on the regression equation in the table above, there are 3 independent variables that significantly influence hedonic behavior, namely sinful acts, usage instagram, and number of followers. The explanation of the regression coefficient values obtained from each of the significant independent variables is as follows;

1. Variables sinful acts obtained a regression coefficient of 0.147 with a significance value of

0.000. This means that $\mathrm{H} 01$ which states "there is no significant influence from sinful acts on hedonic behavior" is rejected. This means that there is a significant influence from sinful acts on hedonic behavior. The coefficient has a positive sign, meaning that the more sinful acts carried out by the student, the higher the hedonic behavior of the students at Syarif Hidayatullah State Islamic University in Jakarta.

2. Instagram usage variables Obtained regression coefficient value of -0.512 with a significance value of 0.040. This means that H05, which states "there is no significant effect of usage Instagram on hedonic behavior" is rejected. The coefficient marked negative means that the higher a person's usage instagram, the lower the hedonic behavior that exists in female students at Syarif Hidayatullah UIN Jakarta.

3. Number of followers variables obtained a regression coefficient of 0.136 with a significance value of 0.040 in a positive direction. This means H09 which states "there is no difference in the number of followers group is high and the number of followers is low" is rejected. The coefficient is positive, meaning that there is a difference in the group of number of followers is high, the hedonic behavior is high as well as the group with low number of followers, the hedonic behavior is low in 
the students at Syarif Hidayatullah State Islamic University in Jakarta

\section{CONCLUSION AND RECOMMENDATION}

\subsection{Conclusion}

This study aims to look at the effect of variables of religiosity, peer attachment, instagram social media characteristics, and demographic factors on hedonic behavior. The results show that the variables sinful acts (dimensions of religiosity) have a significant effect on the positive direction of hedonic behavior. It can be interpreted that the more sinful acts or sins committed, the higher the hedonic behavior. The findings on the variable sinful acts are in line with the theory [51], explaining that hedonic groups tend to spend money because these groups tend to be consumptive. Unlike the utilitarian groups who shop according to their benefits or needs. When a person commits a large or small act of sin affects hedonic behavior which tends to spend his money to meet needs and make someone in a consumptive group.

Glaz's research explains the findings on variable sinful acts, where a person will not display negative behavior when tested with instrumental values that consider God's presence and the absence of God's presence. The negative behavior in question is hedonic behavior that is carried out without considering the presence of God. When a person commits a sin, hedonic behavior is shown to be higher where the student has neglected to maintain instrumental values such as the prohibition of religion in behaving.[52]

Hamzah's research [53] reinforces the findings on variables sinful acts that show that religiosity has a negative influence on hedonic behavior in adolescents. In this study, religiosity was measured using a measurement tool from Krauss (2010) with two dimensions, namely Islamic worldview related to the six pillars of faith or 'harmony of faith' in Islamic teachings and religious personality which includes behavior, motivation, attitudes, and emotions to measure personal manifestations of the teachings and commands of Islam (Krauss, 2011) means that when a person has a high worldview and religious personality, hedonic behavior is shown to be low, where Hamzah explains that the hedonic behavior that is meant psychologically is to pursue excessive sensation and pleasure in his life and ignoring the values of moral goodness in the individual.[54] 
Previous research that explained the use of social media instagram for hedonic behavior was found in the study of Casalo [55]. In this study the characteristic variables of the use of Instagram social media include Instagram usage, Instagram behavior, Instagram attitude, and emotional reactions instagram [56]. The results show that hedonic behavior is influenced by usage variables in negative direction, meaning that when someone spends a lot of time using instagram, the hedonic behavior shown will be less. This is related to the theory presented by Sloan \& Quan-Haase [57]. Instagram provides three benefits for its users, namely (1) enhancing a mediocre appearance in photos by adding applications to "beautify themselves" (2) providing a place to share photos directly from various parts of the world (3) making it easier for users to make uploads directly.

Usage is one important thing to get 3 benefits from Instagram without using it, the benefits cannot be drawn [58]; [59] This can happen because when someone uses Instagram by increasing the appearance of photos, sharing photos and uploading them on the Instagram, the hedonic behavior shown is less. Content and activities that are so broad that one can spend time on the instagram, the less hedonic behavior shown.

This study shows that there are differences in groups that have many number of followers, the hedonic behavior shown is higher. The group whose number of followers is small, the hedonic behavior shown will be lower.

This is a new finding and in line with the theory of Al-Hunaiyyan \& Al-Hajri [60] that followers can see the timeline containing photos and videos from the Instagram account owner. Followers can also interact with what they see by pressing the "like" button and commenting. The author concludes that when a person has many number of followers, a person will have a high hedonic behavior. The timeline that contains photos and videos of Instagram account owners becomes access to the interaction of number of followers with what they see so that it will make someone show a lot of hedonic behavior, and vice versa.

The findings on variable number of followers are supported by Angelstedt and Spetze [61] when a person has a large influence on Instagram with a high number of followers it is considered to be more popular and has popularity [62] The number of followers has a positive influence on consumer behavior in the process of buying and following a brand that is on Instagram. The higher the 
number of a person's followers, the higher the process of buying and following a brand on Instagram because it is considered to have popularity and is liked by many [63]. A large group of number of followers will have a positive influence on showing hedonic behavior such as the process of buying and following a brand on Instagram. This can occur when many groups of number of followers will be considered more favored and have popularity, so the hedonic behavior shown will be higher, and vice versa.

The next finding, it was seen that the content uploaded the most on Instagram was 108 people (32.2\%). This is in line with Hu et.al's research. [64] which analyzes the Instagram content and types of users. The selfie category content is the most choice. Women are one of the ones who show more self and become a popular trend on Instagram social networking sites (Hu et. Al, 2014). The selection of Instagram content obtained in this study is also in line with research that found that selfie $(63.7 \%)$ was the upload category most often uploaded on social media (Tiggemann \& Zaccardo, 2016 in Waninger).

The phenomenon of hedonic behavior described earlier was found in adolescence ([65]; [66], [67];[68]

\& ; [69]; [70]; [71]). Age demographic factors in this study did not significantly affect hedonic behavior. When a person is in his early teens and the final adult according to can have high hedonic behavior, it can also be low [72]. Findings at age can be seen that late adolescents and early adulthood partly influence significantly with other variables. This is supported by research that student age dominates hedonic behavior and according to the phenomena described in the previous chapter. [73]

It can be concluded that the phenomenon that occurred in this study, tested on the students of Syarif Hidayatullah State Islamic University in Jakarta representing Muslim women wearing hijab in the modern era. The author realizes how important it is to limit yourself to avoid hedonic behavior whose orientation is only for pleasure in life. Wisdom in using social media properly is needed. This is also illustrated in the developmental aspects of research in the field of psychology, where the incorporation of aspects of religiosity and social media is a hot topic which is being researched so much that developments on the same theme can 
produce a book entitled "Digital Religion, Social Media and Culture: Perspectives, Practices and Future "(Cheong, Fischer-Nielsen, Gelfgren \& Ess, 2012).

\subsection{RECOMMENDATION}

Future studies are expected to be hedonic behavior variables not only among adolescents or students and conduct research not only on female samples. This can expand the theoretical study of the phenomena that occur in every person who tends to have hedonic behavior among the people. Then, further research can use the "instastories" feature to complete the Instagram variables that are not included in the items listed in this research questionnaire developed by Paramboukis, Skues and Wise [73]. In the next study also can use other psychological variables to be examined, such as social class status, parenting parents.

\section{REFERENCES}

[1] Gulamhussein, Q., \& Eaton, N. R. Hijab, religiosity, and psychological wellbeing of muslim women in the United States. Journal of Muslim Mental Health, 9(2), 25-40. (2015).

[2] Rofhani. Ekspresi dan representasi budaya perempuan Muslim kelas menengah di Surabaya. Islamica: Jurnal Studi Keislaman, Vol. 1, No. 2. p-ISSN:1978-3183;e-ISSN:2356-2218;277-3. (2017).

[3] Bernatta R.A.R. Gaya hidup hedonis di kalangan remaja (Studi pada Komunitas Mobil LSC 81 Club). Skripsi FISIP Universitas lampung. 1-75. (2017).

[4] Casalo L. V., Flavian C., Ibanez-Sanchez S., Understanding consumer interaction on instagram: The role of satisfaction, hedonism, and content characteristics. Cyberpsychology, Behavior, and Social Networking, Vol. 00, No. 00, 1-7. (2017).

[5] Hussin H., \& Abdullah S. Menangani penetrasi budaya hedonisme di kalangan mahasiswa: Satu penyelesaian menurut prespektif Islam dan Kaunseling. Pusat Kemahiran Komunikasi dan Keusahawanan Universiti Kejuruteraan Utara Malaysia. (2014).

[6] Joshanloo, M. \& Jarden, A. Individualism as the moderator of the relationship between hedonism and happiness: A study in 19 nations. Personality and Individual Differences, 94, 149-152. (2016).

[7] Murphy, S. L. \& Eaves, D. L. Exercising for the pleasure and for the pain of it: The implications of different forms of hedonistic thinking in theories of physical activity behavior, Frontiers in Psychology, 7. (2016).

[8] Trimartati N. Studi kasus tentang gaya hidup hedonisme mahasiswa bimbingan dan konseling Universitas Ahmad Dahlan. Psikopedagodia 2014. Vol. 3, No. 1, 1-9. (2014).

[9] Nadzir M. \& Ingarianti T. M. Psychological meaning of money dengan gaya hidup hedonis remaja di kota Malang. Seminar Psikologi dan Kemanusiaan 2015 Psychology Forum UMM, ISBN:978-979-796-324-8, 586-596. (2015).

[10] Trimartati N. Studi kasus tentang gaya hidup hedonisme mahasiswa bimbingan dan konseling Universitas Ahmad Dahlan. Psikopedagodia 2014. Vol. 3, No. 1, 1-9. (2014).

[11] Sholeh A. The Relationship among hedonistic lifestyle, life satisfaction, and happiness on college students. International Journal of Social Science and Humanity, Vol. 7, Vol. 9, 1-5. (2017).

[12] Saputri. A., \& Rachmatan. R. Religiusitas dengan gaya hidup hedonisme: Sebuah gambaran pada mahasiswa Universitas Syiah Kuala. Jurnal Psikologi, Vol. 12. (2016).

[13] Nadzir M. \& Ingarianti T. M. Psychological meaning of money dengan gaya hidup hedonis remaja di kota Malang. Seminar Psikologi dan Kemanusiaan 2015 Psychology Forum UMM, ISBN:978-979-796-324-8, 586-596. (2015). 
[14] Hamzah, S. R., Suandi, T., Krauss, S. E., Hamzah, A. \& Tamam, E. Youth hedonistic behaviour: moderating role of peer attachment on the effect of religiosity and worldview, International Journal of Adolescence and Youth, 19, 4, 419-433. (2014).

[15] Trimartati N. Studi kasus tentang gaya hidup hedonisme mahasiswa bimbingan dan konseling Universitas Ahmad Dahlan. Psikopedagodia 2014. Vol. 3, No. 1, 1-9. (2014).

[16] Hamzah, S. R., Suandi, T., Krauss, S. E., Hamzah, A. \& Tamam, E. Youth hedonistic behaviour: moderating role of peer attachment on the effect of religiosity and worldview, International Journal of Adolescence and Youth, 19, 4, 419-433. (2014).

[17] Hamzah, S. R., Suandi, T., Krauss, S. E., Hamzah, A. \& Tamam, E. Youth hedonistic behaviour: moderating role of peer attachment on the effect of religiosity and worldview, International Journal of Adolescence and Youth, 19, 4, 419-433. (2014).

[18] Engel, J. F. Balckwel, R. D. \& Miniard, P. W. Perilaku Konsumen. Jilid I. Alih Bahasa: F. X. Budiyanto. Jakarta: Bina Seni Rupa Aksara. (1993).

[19] Hamzah, S. R., Krauss, S., Suandi, T., Hamzah, A., \& Tamam, E. The influence of religiosity, parental and peer attachment on hedonistic behavior among Malaysian youth. Procedia-Social and Behavioral Sciences, 122, 393-397. (2013)

[10] Hamzah, S. R., Suandi, T., Krauss, S. E., Hamzah, A. \& Tamam, E. Youth hedonistic behaviour: moderating role of peer attachment on the effect of religiosity and worldview, International Journal of Adolescence and Youth, 19, 4, 419-433. (2014).

[21] Furman, W \& Bierman K.L. Children's conceptions of friendship: A multimethod study of developmental changes. Dev Psychology. 1984 September ; 20(5): 925-931. doi:1037/0012-1649.20.5.925. (1984).

[22] Wilkinson, R. B. Development and properties of the adolescent friendship attachment scale. Journal of Youth and Adolescence, 37. (2008).

[23] Casalo L. V., Flavian C., Ibanez-Sanchez S., Understanding consumer interaction on instagram: The role of satisfaction, hedonism, and content characteristics. Cyberpsychology, Behavior, and Social Networking, Vol. 00, No. 00, 1-7. (2017).

[24] Jang J. Y., Han K., Shih P. C., p D., Generation like: Comparative characteristics in Instagram, CHI, DOI: 10.1145/2702123.2702555. Retrived from [http://pike.psu.edu/publications/chi15.pdf]. (2015).

[25] Casalo L. V., Flavian C., Ibanez-Sanchez S., Understanding consumer interaction on instagram: The role of satisfaction, hedonism, and content characteristics. Cyberpsychology, Behavior, and Social Networking, Vol. 00, No. 00, 1-7. (2017).

[26] Alhabash, S., \& MA A tale of four platforms: motivations and uses of facebook, twitter, instagram, and snapchat among college students?: Journals.sagepub.com/home/sns. Social Media + Society January-March :1-13. (2017).

[27] Al-Hunaiyyan A. A., Al-Hajri R., The influence of culture on instagram use. Journal of Advances in Information Technology, 7, 1, 54-57. (2016).

[28] Hu Y., L \& Manikonda L., Khambapati S. What we Instagram: A first analysis Instagram photo content and user types. Proceeding of the Eighth International AAAI Conference on Weblogs and Social Media, 14. [https://www.aaai.org/ocs/index.php/ICWSM/IC WSM14/paper/viewFile/8118/8087]. (2014).

[29] Jang J. Y., Han K., Shih P. C., p D., Generation like: Comparative characteristics in Instagram, CHI, DOI: 10.1145/2702123.2702555. Retrived from [http://pike.psu.edu/publications/chi15.pdf]. (2015).

[30] Buhr E. Virtue and positive psychology: examining hedonism. Trinity Western University. (2013).

[31] Hamzah, S. R., Suandi, T., Krauss, S. E., Hamzah, A. \& Tamam, E. Youth hedonistic behaviour: moderating role of peer attachment on the effect of religiosity and worldview, International Journal of Adolescence and Youth, 19, 4, 419-433. (2014).

[32] Hamzah, S. R., Krauss, S., Suandi, T., Hamzah, A., \& Tamam, E. The influence of religiosity, parental and peer attachment on hedonistic behavior among Malaysian youth. Procedia-Social and Behavioral Sciences, 122, 393-397. (2013). 
[33] American Psychological Association. APA dictionary of psychology (2nd ed.). Washington, DC: American Psychological Association. (2015).

[34] Olufadi, Y. Muslim daily religiosity assessment scale (MUDRAS): A New instrument for Muslim religiosity research and practice. Psychology of Religion and Spirituality, 1-15. [http://dx.doi.org/10.1037/re10000074]. (2016).

[35] Armsden G. C., E. Greenberg M. T. The inventory of parent and peer attachment: Individual differences and their relationship to psychological well-being in adolescence. Journal of Youth and Adolescence, 16, 5, 427-454. (1987).

[36] Hamzah, S. R., Suandi, T., Krauss, S. E., Hamzah, A. \& Tamam, E. Youth hedonistic behaviour: moderating role of peer attachment on the effect of religiosity and worldview, International Journal of Adolescence and Youth, 19, 4, 419-433. (2014).

[37] Hamzah, S. R., Suandi, T., Krauss, S. E., Hamzah, A. \& Tamam, E. Youth hedonistic behaviour: moderating role of peer attachment on the effect of religiosity and worldview, International Journal of Adolescence and Youth, 19, 4, 419-433. (2014).

[38] Wilkinson, R. B. Development and properties of the adolescent friendship attachment scale. Journal of Youth and Adolescence, 37. (2008).

[39] Armsden G. C., E. Greenberg M. T. The inventory of parent and peer attachment: Individual differences and their relationship to psychological well-being in adolescence. Journal of Youth and Adolescence, 16, 5, 427-454. (1987).

[40] Casalo L. V., Flavian C., Ibanez-Sanchez S., Understanding consumer interaction on instagram: The role of satisfaction, hedonism, and content characteristics. Cyberpsychology, Behavior, and Social Networking, Vol. 00, No. 00, 1-7. (2017).

[41] Yang, C. Instagram use, loneliness, and social comparison orientation: Interact and browse on social media, but don't compare. Cyberpsychology, behavior, and social networking, 1-6. (2016).

[42] Yang, C. Instagram use, loneliness, and social comparison orientation: Interact and browse on social media, but don't compare. Cyberpsychology, behavior, and social networking, 1-6. (2016).

[43] Yang, C. Instagram use, loneliness, and social comparison orientation: Interact and browse on social media, but don't compare. Cyberpsychology, behavior, and social networking, 1-6. (2016).

[44] M. Kleemans et. Picture perfect: The direct effect of manipulated Instagram photos on body image in adolescent girls. Media Psychology. [http://dx.doi.org/10/1080/15213269.2016.1257392], 1-18. Al (2016).

[45] Yang, C. Instagram use, loneliness, and social comparison orientation: Interact and browse on social media, but don't compare. Cyberpsychology, behavior, and social networking, 1-6. (2016).

[46] Casalo L. V., Flavian C., Ibanez-Sanchez S., Understanding consumer interaction on instagram: The role of satisfaction, hedonism, and content characteristics. Cyberpsychology, Behavior, and Social Networking, Vol. 00, No. 00, 1-7. (2017).

[47] M. Kleemans et. Picture perfect: The direct effect of manipulated Instagram photos on body image in adolescent girls. Media Psychology. [http://dx.doi.org/10/1080/15213269.2016.1257392], 1-18. Al (2016).

[48] Olufadi, Y. Muslim daily religiosity assessment scale (MUDRAS): A New instrument for Muslim religiosity research and practice. Psychology of Religion and Spirituality, 1-15. [http://dx.doi.org/10.1037/rel0000074]. (2016).

[49] Armsden G. C., E. Greenberg M. T. The inventory of parent and peer attachment: Individual differences and their relationship to psychological well-being in adolescence. Journal of Youth and Adolescence, 16, 5, 427-454. (1987).

[50] M. Kleemans et. Al Picture perfect: The direct effect of manipulated Instagram photos on body image in adolescent girls. Media Psychology. [http://dx.doi.org/10/1080/15213269.2016.1257392], 1-18. (2016).

[51] Nadzir M. \& Ingarianti T. M. Psychological meaning of money dengan gaya hidup hedonis remaja di kota Malang. Seminar Psikologi dan Kemanusiaan 2015 Psychology Forum UMM, ISBN:978-979-796-324-8, 586-596. (2015). 
[52] Paramboukis, O., Skues, J., Wise, L. An exploratory study of the relationships between narcissism, selfesteem and Instagram use. Social Networking, 5, 82-92. (2016).

[53] Hamzah, S. R., Suandi, T., Krauss, S. E., Hamzah, A. \& Tamam, E. Youth hedonistic behaviour: moderating role of peer attachment on the effect of religiosity and worldview, International Journal of Adolescence and Youth, 19, 4, 419-433. (2014).

[54] Hamzah, S. R., Suandi, T., Krauss, S. E., Hamzah, A. \& Tamam, E. Youth hedonistic behaviour: moderating role of peer attachment on the effect of religiosity and worldview, International Journal of Adolescence and Youth, 19, 4, 419-433. (2014).

[55] Casalo L. V., Flavian C., Ibanez-Sanchez S., Understanding consumer interaction on instagram: The role of satisfaction, hedonism, and content characteristics. Cyberpsychology, Behavior, and Social Networking, Vol. 00, No. 00, 1-7. (2017).

[56] M. Kleemans et. Al Picture perfect: The direct effect of manipulated Instagram photos on body image in adolescent girls. Media Psychology. [http://dx.doi.org/10/1080/15213269.2016.1257392], 1-18. (2016).

[57] Glaz, S. Instrumental values as predictors of religious experience in the lives of students of pedagogy and of philosophy. Religions, 860-874(4); doi 10.3390/rel6030860. (2015).

[58] Alhabash, S., \& MA A tale of four platforms: motivations and uses of facebook, twitter, instagram, and snapchat among college students?: Journals.sagepub.com/home/sns. Social Media + Society January-March :1-13. (2017).

[59] Sloan, L., \& Haase Q. A. The SAGE Handbook of Social Media Research Methods. SAGE reference, British Library;UK. (2017).

[60] Al-Hunaiyyan A. A., Al-Hajri R., The influence of culture on instagram use. Journal of Advances in Information Technology, 7, 1, 54-57. (2016).

[61] Ting, C. C. A study of motives, usage, self-presentation and number of followers of Instagram. Discovery - SS Student E-Journal, 3, 1-35. (2014).

[62] Angelstedt N. A \& Spetz, J. The more the merrier? A study of fashon followers on Instagram and their influence on purchase intention. Bachelor's Programme in International Marketing, 180 credits. Halmstad University, 1-133. (2017).

[63] Collins, N. L. Working models of attachment: Implications for explanation, emotion, and behavior. Journal of Personality and Social Psychology, 71, 810-832. (1996).

[64] Hu Y., L \& Manikonda L., Khambapati S. What we Instagram: A first analysis Instagram photo content and user types. Proceeding of the Eighth International AAAI Conference on Weblogs and Social Media, 14. [https://www.aaai.org/ocs/index.php/ICWSM/IC WSM14/paper/viewFile/8118/8087]. (2014).

[65] Bernatta R.A.R. Gaya hidup hedonis di kalangan remaja (Studi pada Komunitas Mobil LSC 81 Club). Skripsi FISIP Universitas lampung. 1-75. (2017).

[66] Casalo L. V., Flavian C., Ibanez-Sanchez S., Understanding consumer interaction on instagram: The role of satisfaction, hedonism, and content characteristics. Cyberpsychology, Behavior, and Social Networking, Vol. 00, No. 00, 1-7. (2017).

[67] Hussin H., \& Abdullah S. Menangani penetrasi budaya hedonisme di kalangan mahasiswa: Satu penyelesaian menurut prespektif Islam dan Kaunseling. Pusat Kemahiran Komunikasi dan Keusahawanan Universiti Kejuruteraan Utara Malaysia. (2014).

[68] Joshanloo, M. \& Jarden, A. Individualism as the moderator of the relationship between hedonism and happiness: A study in 19 nations. Personality and Individual Differences, 94, 149-152. (2016).

[69] Murphy, S. L. \& Eaves, D. L. Exercising for the pleasure and for the pain of it: The implications of different forms of hedonistic thinking in theories of physical activity behavior, Frontiers in Psychology, 7. (2016).

[70] Trimartati N. Studi kasus tentang gaya hidup hedonisme mahasiswa bimbingan dan konseling Universitas Ahmad Dahlan. Psikopedagodia 2014. Vol. 3, No. 1, 1-9. (2014). 
[71] Nadzir M. \& Ingarianti T. M. Psychological meaning of money dengan gaya hidup hedonis remaja di kota Malang. Seminar Psikologi dan Kemanusiaan 2015 Psychology Forum UMM, ISBN:978-979-796-324-8, 586-596. (2015).

[72] Sholeh A. The Relationship among hedonistic lifestyle, life satisfaction, and happiness on college students. International Journal of Social Science and Humanity, Vol. 7, Vol. 9, 1-5. (2017).

[73] Saputri. A., \& Rachmatan. R. Religiusitas dengan gaya hidup hedonisme: Sebuah gambaran pada mahasiswa Universitas Syiah Kuala. Jurnal Psikologi, Vol. 12. (2016). 


\section{APPENDIX}

SYNTAX \& PATH DIAGRAM PERILAKU HEDONIS

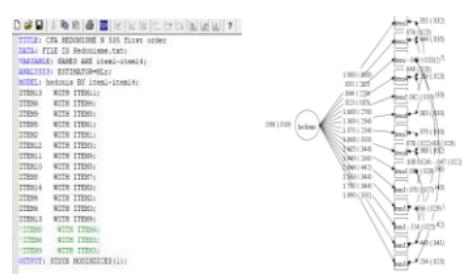

SYNTAX \& PATH DIAGRAM SINFUL ACTS

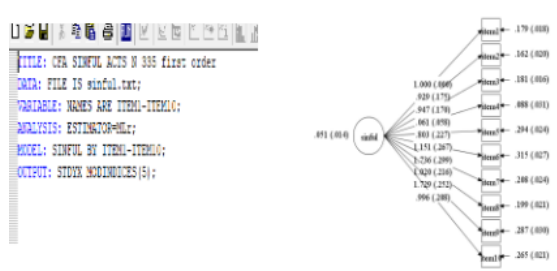

SYNTAX \& PATH DIAGRAM RECOMMENDED ACTS
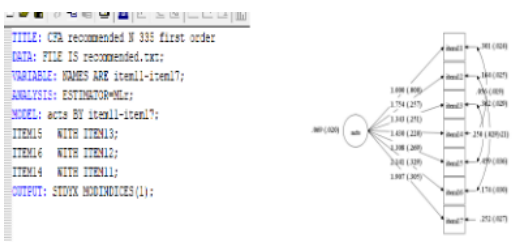

SYNTAX \& PATH DIAGRAM ENGAGING IN BODILY WORSHIP OF GOD
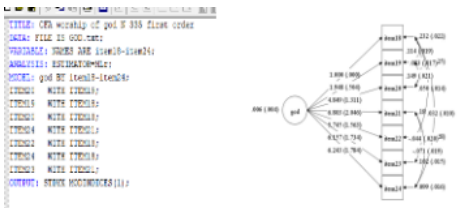

SYNTAX \& PATH DIAGRAM PEER ATTACHMENT

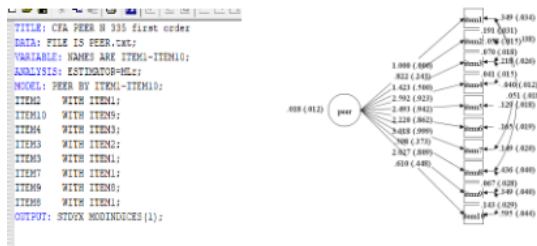

SYNTAX \& PATH DIAGRAM INSTAGRAM
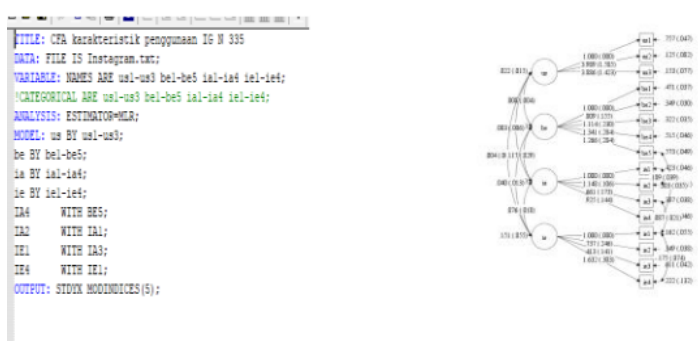
